\title{
FRAMEWORK FOR ASSESSING THE STRUCTURE OF CORPORATE INTANGIBLE ASSETS
}

\author{
Rita Bužinskienè $\dot{1}^{1, \mathrm{a}, *}$ \\ ${ }^{1}$ Siauliai State College, Ausros Av. 40, Siauliai, Lithuania \\ aritabuzin@gmail.com \\ *Corresponding author
}

Cite as: BUZINSKIENE, R. (2019). Framework for assessing the structure of corporate intangible assets. Ekonomicko-manazerske spektrum, 13(2), 10-27.

Available at: dx.doi.org/10.26552/ems.2019.2.10-27

\begin{abstract}
Disclosure of intangible assets has become an important factor for corporate performance. The problem is that the fair value of intangible assets is therefore still not fully disclosed. In order to measure the value of intangible assets, the article outlines how the determination of the structure of intangible assets, can be useful in companies as a means to better understand the management of business value. Therefore, in order to increase business value, companies and their managers need a better understanding of the measurement of the intangible asset structure and differences in the accounting rules for the evaluation of intangible assets. The main results indicated, that the general structure on the intangible assets has differences between financial and nonfinancial information that is not beneficial to an enterprise, as it loses the opportunity to disclose the true value of an intangible asset. An important aspect of this article is the establishment of a methodology for the structure of intangible assets, under which companies should reduce the lack of accounting information on intangible assets.
\end{abstract}

Keywords: corporate intangible assets, financial information, nonfinancial information, general structure, measurement

JEL Classification: M41, M21

\section{Introduction}

The pace of economic growth, people's social welfare and sustainable development of the economy are increasingly dependent on the creation of new knowledge and practical application of it. The activities of the company are related to different types of resources, among which intangible assets are becoming an increasingly important incentive for the company to operate. At the end of the twentieth century, the increased interest in intangible assets and its impact on the market value of companies encouraged companies to increase their investment in human resources, research, and development, new technologies, etc. To maintain a competitive advantage and increase the value of shares in the market, the true value of intangible assets in the balance remains important, as it also determines the value of the companies on the market.

Despite the growing importance of intangible assets in the process of companies ${ }^{6}$ value creation, most of them are not accounted for and do not reflect in traditional financial accounting. Typically, only some types of intangible assets are recorded in the balance-sheet: goodwill, licenses, copyrights, software, development, and research. Issues and uncertainties regarding the estimation of the value of intangible assets are still not resolved. Intangible 
assets are only accounted for such resources whose costs meet the definition of intangible assets and recognition criteria: future economic benefits, value, and control. Solving the problems of determining the value of intangible assets people encounter with a lack of disclosure of accounting information. Proper disclosure of accounting information is based on fairness and equality of rights. Otherwise, incorrectly disclosed information suggests opportunities to unfair competition in the securities market. The reliability of accounting information in the quality area is ensured by external institutions that are focused on disclosure and publicity.

The recognition of intangible assets as intangible assets in the financial statements is considered complicated by the definition of this assets, i.e. by identifying it, determining its value, proving future economic benefits and ensuring control. Most researchers Bontis (1998); Teece (2000); Lönnqvist and Mettänen (2002); Lev (2003); Lev and Daum (2004); Volkov and Garanina (2007); Kisgern et. al. (2009); Jukaitytė-Sungailienè (2009); Crema and Nosella (2014); Svensson (2014); Kimouche and Rouabhi (2016); Rajiv et al. (2019) agree that the totality of intangible assets belonging to the company includes the integrity of the intangible assets, which is disposed of by the need and purpose. However, the incompatibility lies with the possibility of accounting for these resources, using recognition criteria following generally accepted accounting standards. It is precise because of conservative accounting standards that most intangible assets are not accounted for and are not reflected in the financial statements. Only a small part of the intangible assets account is recognized, measured and disclosed as intangible assets.

Scientists Shah and Khedkar (2006); Mačerinskienė and Survilaitė (2011); Sofian et al. (2011); Rudžionienė and Ramanauskaitė (2012); Stankevičienė and Liučvaitienė (2012); Jaara and Elkotayni (2016); Ahn (2019); Ferdaous and Rahman (2019) confirms that most companies account for intangible assets as expenses, while the costs necessary to form these assets are regarded as the spending of that period, resulting in a decrease of owners' capital. Notation of intangible assets together with other company's expenses have a direct impact on companies' results: profit and taxes.

In principle, researchers are solving different problems: what value of intangible assets are disclosed in the financial statements; how the intangible assets structure is changing in various industrial sectors; to what extent unrecorded intangible assets value exceeds the fair value of the intangible assets; what is the relationship between the market value of intangible assets and companies? What is the gap between the fair and market value of the companies on the securities market? However, the vast majority of such studies are related to other countries: the USA, Switzerland, England, France, India, Malaysia, and others. An important role is played by international organizations which, to increase the disclosure of financial information and its comparison between economic entities and other market participants, develop and improve common international accounting standards. In Lithuania, this area was explored in a fragmented way. In recent years, more studies are showing that the topic is relevant in the world and Lithuania.

Research problem - this paper analyzes the problem of the research: What framework have to prefer for measuring the structure of financial and nonfinancial information on corporate intangible assets?

The purpose of the research - after analyzing the framework for the measurement of financial and nonfinancial information on intangible assets, to test a method for determining the structure of financial and nonfinancial information on intangible assets in Lithuania's companies. 


\section{Methodology}

For measuring the structure of financial and nonfinancial information on the intangible assets was applied 2 stages: 1. Way of measuring of the structure of financial and nonfinancial information on the intangible assets. 2. The determination of elements of general intangible assets.

Stage 1. This stage shows the way for measuring of the structure of financial and nonfinancial information on the intangible assets (Table 1).

Table 1: Framework for measurement of financial and nonfinancial information on the intangible assets

\begin{tabular}{|l|l|l|}
\hline Steps & Denomination & Results \\
\hline 1 & $\begin{array}{l}\text { Selection of intangible assets } \\
\text { elements and their subelements } \\
\text { for research }\end{array}$ & $\begin{array}{l}\text { The classification of intangible assets is determined by the } \\
\text { frequency of the recurrence of the subelements. The subelements } \\
\text { that were repeated more than once were selected for the study. } \\
\text { Each subelement is assigned to an intangible asset element. }\end{array}$ \\
\hline 3 & $\begin{array}{l}\text { Accounting for the value of } \\
\text { financial information on } \\
\text { intangible assets }\end{array}$ & $\begin{array}{l}\text { According to accounting standards, the value calculate assigned } \\
\text { to each element of financial information on the intangible assets } \\
\text { is recognized as fixed assets. }\end{array}$ \\
\hline 3 & $\begin{array}{l}\text { The coding system of the } \\
\text { informats of nonfinancial } \\
\text { assets. It is not recognized by } \\
\text { the general accounting } \\
\text { principles as intangible assets }\end{array}$ & $\begin{array}{l}\text { The recognition of intangible assets elements and their } \\
\text { subelements involves the structure of intangible assets that don't } \\
\text { recognize in the accounting system. }\end{array}$ \\
\hline
\end{tabular}

Source: Januškevičius, R. \& Januškevičienė, O. (2006). Elementarusis tikimybių ir statistikos kursas informatikams. Vilniaus Pedagoginis Universitetas, 20-21.

Step 1. In the classification of intangible assets, the first step is to investigate the selection of elements of intangible assets and their subelements. Sampling is a method of selecting the right sample. Specially adapted frequency measurement method. Frequency is the number of certain types of events or the number of observations that have occurred in a particular class, Januškevičius and Januškevičienè (2006). When a large sample of random sizes is available, it is often difficult to cover and interpret. The frequency of the variable $\mathrm{X}$ value $f i$ indicates how often this value is found in the sample. It is clear that the sum of $f i$ for all frequencies is equal to the number of observations $n$ :

$$
\sum_{i=t}^{\mathrm{n}} \mathrm{fi}=n
$$

By expressing the results with numerical characteristics by groups, the data is processed quantitatively. Each observation should only be assigned to one of several groups. Such data is usually presented as a frequency table and shows the number (frequency) of each group element. The ratio of this frequency to the total number of observations is called relative frequency, Januškevičius and Januškevičienè (2006).

The selection of subelements of intangible assets showed that the largest number of observations compared to the total number of observations was innovative assets. In this group of assets, 17 subelements were repeated 61 times and amounted to about 0.34 rates (Table 2). The assets invested in human-centered include 10 subelements with a recurrence frequency of 29 times i.e about 0.16 coef. Seven subelements were identified in the customerrelated 21 times, and their frequency ratio was 0.12 coef. Contract-based assets are distributed 
equally, at around 0.11 coef., although the number of sub-elements differs, respectively at 5 and 7.

Table 2: Data for the selection of subelements on the intangible assets

\begin{tabular}{|c|c|c|c|}
\hline & $\begin{array}{l}\text { Number of } \\
\text { observations } \\
\text { (subelements) }\end{array}$ & Frequency & Relative frequency \\
\hline Marketing-related & 5 & 19 & 0.11 \\
\hline Human-centered & 10 & 29 & 0.16 \\
\hline Contract-based & 7 & 19 & 0.11 \\
\hline Technology-based & 4 & 14 & 0.08 \\
\hline Innovative- related & 17 & 61 & 0.34 \\
\hline Customer-related & 7 & 21 & 0.12 \\
\hline Artistic-related & 5 & 10 & 0.06 \\
\hline Goodwill & 2 & 4 & 0.02 \\
\hline Total: & 57 & 177 & 1.00 \\
\hline
\end{tabular}

Source: Sveiby (1997), Bontis (1998), Wyatt and Abernethy (2003), Corrado et al. (2005), Pekkola (2011), OECD (2013), Rider and et. al. (2019), Sun and et al. (2019)

Technology-based assets include 4 subelements, with a recurrence frequency of 14 times, i.e about 0.08 coef. Artistic-related consists of 5 subelements, with a recurrence frequency of 10 times, i.e about 0.06 coef. The lowest number of subelements has distinguished goodwill, i.e 2 sub-elements with a recurrence frequency of about 0.02 coef. In total, 57 subelements of intangible assets were selected for the study. They grouped into 8 elements of intangible assets.

Step 2. In calculating the value of financial information intangible assets, it was chosen to adopt the historical pricing system (International Accounting Standards (IAS 38 - Intangible Assets), International Financial Reporting Standards (IFRS3), Generally accepted accounting principles (GAAP)). Researchers, using empirical evidence to determine the impact of an intangible asset on the market value of companies, most often used the balancesheet value at the end of the year. The carrying amount is the cost of acquisition of the intangible asset during the period, which is reduced by the amortization amount. However, the amortization amount represents the part of the value of the intangible assets that were used during the accounting year, which determined the market value of the company. So, the value of financial information on intangible assets that are used in the company's operations during the accounting year is higher, and the carrying amount at the end of the year reflects the reduced value of the asset. Therefore, I propose to calculate the value of financial information on intangible assets in the following sequence:

$$
F I N T_{i t}=N T B V_{\text {it }}+N T A_{i t}
$$

Where:

$F I N T_{i t}$ the value of financial information on the intangible assets of the company at the end of the accounting year, (eur)

$N T B V_{\mathrm{it}}$ the balance value of the intangible assets of the company at the end of the accounting year, (eur)

$N T A_{i t}$ the value of amortization of the intangible assets of the company at the end of the accounting year, (eur) 
Step 3. In the third step of the method, the quantitative content analysis method was chosen to identify of elements of nonfinancial information on the intangible assets (Table 3).

Before determination of the structure of nonfinancial information on the intangible assets, companies were chosen for participation on the research by following criteria: company's business value, financial information on the intangible assets (FINT), nonfinancial information on the intangible assets (NINT), industry, set of financial statements and annual reports of the period of years 2009-2015.

Table 3: Method of quantitative content analysis

\begin{tabular}{|l|l|l|}
\hline Steps & Indicator & Description \\
\hline 1 & $\begin{array}{l}\text { The research sample and } \\
\text { period }\end{array}$ & $\begin{array}{l}\text { Financial statements, annual reports, additional information for } \\
\text { investors of } 18 \text { companies. Research period: 2009-2015. }\end{array}$ \\
\hline 2 & $\begin{array}{l}\text { The object of research is } \\
\text { the nonfinancial } \\
\text { information on the } \\
\text { intangible assets }\end{array}$ & $\begin{array}{l}\text { Elements of 7 intangible assets, consisting of 46 subelements: a) } \\
\text { marketing-related - 3; b) human-centered - 10; c) contract-based - } \\
3 ; \mathrm{d} \text { ) technology-based - 2; e) innovation-related - 17; f) customer- } \\
\text { related - 6; g) artistic-related - 5. }\end{array}$ \\
\hline 3 & $\begin{array}{l}\text { The units of measurements } \\
\text { 1. Text information tools: sentences, phrases, messages and other } \\
\text { text. 2. Visual media tools: paintings, graphs, charts and others. }\end{array}$ \\
\hline 4 & $\begin{array}{l}\text { The scale of assessment for } \\
\text { nonfinancial information on } \\
\text { the intangible assets }\end{array}$ & $\begin{array}{l}\text { Nominal scale (qualitative data classification) selected for the } \\
\text { assessment of variables: 0 - neutral/none; } 1 \text { - not very important/is; } \\
2-\text { significant/is; } 3 \text { - very significant/continuously improved and } \\
\text { developed. }\end{array}$ \\
\hline 5 & $\begin{array}{l}\text { The coding system for the } \\
\text { elements of nonfinancial } \\
\text { information on the } \\
\text { intangible assets }\end{array}$ & $\begin{array}{l}\text { According to the coding system for nonfinancial information on } \\
\text { intangible assets, identify the elements of assets that have been } \\
\text { assigned the appropriate scores (Table 10). }\end{array}$ \\
\hline
\end{tabular}

Source: Rodov, I. \& Leliaert, P. (2002). FiMIAM: Financial method of intangible assets measurement. Journal of Intellectual Capital: Measuring intellectual capitalism, 3(3), 323-336.

The study uses data from 18 companies' financial statements and annual reports. The financial and nonfinancial information on the intangible assets presented in these reports is considered as the main financial source. This information is publicly available and freely accessible to each external user of the information. The research size was determined according to the formula of Schwarze (1993):

$$
n=\frac{N * 1.96^{2} * p^{*} q}{\varepsilon^{2} *(N-1)+1.96^{2} * p^{*} q}
$$

Where:

$n$ research size

1,96 value corresponds to a standardized $95 \%$ confidence level of a normal distribution

$p \quad$ the probability of the expected end of the event that the attribute in question will occur in the population under study (most often the worst-case scenario is attributed to half, that is, $50 \%$ of the population, and $\mathrm{p}=0.5$ )

$q$ the probability that the trait under consideration will not occur in the population under study $(\mathrm{q}=1-\mathrm{p}=0,5)$

$\varepsilon \quad$ desirable accuracy, usually $\varepsilon=0,05$

To perform a comparative analysis, different industries were selected for research and grouped into two large groups: manufacturing and services. The size of the research was found to consist of 9 services and 9 manufacturing enterprises. The main activities of the services group are telecommunications, financial, industrial and utilities. The activities of the 
group of manufacturing companies include the production and marketing of food and beverages, clothing, textiles, household paper, household appliances, alcohol, construction materials.

Text, visual, graphical information, and other text derivatives whose unit of measurement meets certain coding scale criteria are used to identify nonfinancial information on the intangible assets. According to Kasiulevičius and Denapiene (2008), qualitative data classification is often used to form the coding scale or a grouping, the sample of which is broken down by the categories of these variables. Numbers that encode individual objects or their properties do not have any empirical meaning, but only indicate what a feature is or object. The processing options of the variables belonging to the nominal scale are rather limited - it is only possible to estimate which objects are more or less, the total number of objects in the list. Equal statistical tests are applied to the partial samples obtained, and their results are compared against each other. According to Krippendorff (2013), content analysis is a scientific tool that requires a special preparation procedure. He suggests that the results of the study be calculated according to the scale of evaluation developed by Janis and Fadner (1965): $f=$ significant number of units; $u=$ an insignificant unit of numbers; $r=$ significant number units $=u+f+$ neutral number unit; $t=$ total number of units $=r+$ unimportant number unit.

Based on the computational logic outlined, the coding system is based on the existing nonfinancial information type of intangible assets in a company that is rated on a scale of 0 to 3 (Table 4 ).

Table 4: The coding system of nonfinancial information on the intangible assets

\begin{tabular}{|c|c|c|}
\hline $\begin{array}{l}\text { Elements of } \\
\text { NINT }\end{array}$ & Subelements & Subelement values \\
\hline \multirow{3}{*}{$\begin{array}{l}\text { Marketing- } \\
\text { related }\end{array}$} & Brand signs & Brand creation, renewal, and use in product promotion \\
\hline & $\begin{array}{l}\text { Information } \\
\text { headlines }\end{array}$ & Investing in web page creation and other sources of information \\
\hline & $\begin{array}{l}\text { Non-competitive } \\
\text { agreements }\end{array}$ & Agreements on the development of joint projects \\
\hline \multirow{10}{*}{$\begin{array}{l}\text { Human- } \\
\text { centered: }\end{array}$} & Wage / Salary & $\begin{array}{l}\text { Employee remuneration system: basic, variable, and additional benefits, and } \\
\text { social guarantees }\end{array}$ \\
\hline & Expert knowledge & Cooperation with educational institutions. Development of expert knowledge \\
\hline & Education & $\begin{array}{l}\text { Leading staff with high or higher education, senior staff, spec. secondary, } \\
\text { secondary, incomplete secondary education }\end{array}$ \\
\hline & Experience & $\begin{array}{l}\text { The average length of service in the company. Employee sharing experience, } \\
\text { offering ideas and giving suggestions }\end{array}$ \\
\hline & $\begin{array}{l}\text { Employee } \\
\text { competence }\end{array}$ & $\begin{array}{l}\text { Improving workers' practical skills: sharing knowledge, experiences, teaching } \\
\text { employees, creating programs }\end{array}$ \\
\hline & Loyalty & $\begin{array}{l}\text { Nonfinancial reward: events, congratulations, recognition and appreciation for } \\
\text { the best employee }\end{array}$ \\
\hline & Skills & Implementation of employee skills development programs \\
\hline & Training & Funds are allocated for training, upgrading, improvement, and cooperation \\
\hline & Innovation & $\begin{array}{l}\text { Various applications are underway for staff: leadership, law, sales, personnel } \\
\text { management, marketing, customer service, stress management, and innovative } \\
\text { training techniques }\end{array}$ \\
\hline & Motivation & Funds are allocated to motivate the work environment \\
\hline \multirow{2}{*}{$\begin{array}{l}\text { Contract- } \\
\text { based }\end{array}$} & Promotional Ads & $\begin{array}{l}\text { Advertising, marketing costs for increasing sales, strengthening public } \\
\text { relations }\end{array}$ \\
\hline & $\begin{array}{l}\text { Building permits, } \\
\text { copyright }\end{array}$ & $\begin{array}{l}\text { Received permissions, certificates. Funds for intelligent technology } \\
\text { deployment rights, etc. }\end{array}$ \\
\hline $\begin{array}{l}\text { Technology- } \\
\text { based }\end{array}$ & $\begin{array}{l}\text { Technology } \\
\text { patenting }\end{array}$ & $\begin{array}{l}\text { Investing in the development of new technologies, production of new } \\
\text { products, environmental systems and so on. }\end{array}$ \\
\hline
\end{tabular}




\begin{tabular}{|c|c|c|}
\hline \multirow{11}{*}{$\begin{array}{l}\text { Innovative- } \\
\text { related }\end{array}$} & $\begin{array}{l}\text { Research and } \\
\text { development costs } \\
\text { incurred by industry }\end{array}$ & $\begin{array}{l}\text { Assigning long-term investments to develop high-tech activities into product } \\
\text { quality research, and development, planning of innovative performance } \\
\text { optimization tools, ensuring investment upgrades and level of modernization }\end{array}$ \\
\hline & $\begin{array}{l}\text { Scientific and } \\
\text { technological } \\
\text { research and } \\
\text { development }\end{array}$ & $\begin{array}{l}\text { Funds for diagnostics of new products, technical condition, market } \\
\text { development, and other activities and processes. Investment in technology } \\
\text { research, modernization, and deployment }\end{array}$ \\
\hline & $\begin{array}{l}\text { Product } \\
\text { development }\end{array}$ & Investing in research and renewal of new products \\
\hline & Market Research & Investing in market research for maintaining and increasing competition \\
\hline & Creative capital & $\begin{array}{l}\text { Continuity of long-term investment in the development of new technologies. } \\
\text { Modernization of environmental protection processes. Developing models to } \\
\text { assess the appropriateness of technology }\end{array}$ \\
\hline & Publications & Presentation of online publications on the rational use of products/services \\
\hline & Data, Inventions & Performed tests, tests in laboratories \\
\hline & Strategy & $\begin{array}{l}\text { Funds for long-term business strategy: market liberalization, innovation, and } \\
\text { operational efficiency; services are one of the strategic activities }\end{array}$ \\
\hline & $\begin{array}{l}\text { Market and } \\
\text { Competitive } \\
\text { Insights }\end{array}$ & $\begin{array}{l}\text { Funds to maintain market leadership, strengthen competitiveness, meet the } \\
\text { needs of existing customers, grow the value of your business, maintain your } \\
\text { market }\end{array}$ \\
\hline & $\begin{array}{l}\text { Organizational } \\
\text { culture }\end{array}$ & $\begin{array}{l}\text { Introduction of new management structure, innovative activity system, } \\
\text { optimization. The company has established new divisions for specific tasks }\end{array}$ \\
\hline & $\begin{array}{l}\text { Organization } \\
\text { routine }\end{array}$ & $\begin{array}{l}\text { Funds for developing customer service, and information channels to shape } \\
\text { organizational processes }\end{array}$ \\
\hline \multirow{5}{*}{$\begin{array}{l}\text { Customer- } \\
\text { related }\end{array}$} & $\begin{array}{l}\text { Non-contractual } \\
\text { customer } \\
\text { relationships }\end{array}$ & $\begin{array}{l}\text { Investing in long-term contracts with charitable foundations, customers, and } \\
\text { suppliers. Ensuring overall growth in the number of users }\end{array}$ \\
\hline & Buyer lists & Investing in connecting new users, creating channels, etc. \\
\hline & Customer Retention & $\begin{array}{l}\text { Funds to improve and deploy customer service quality, upgrade information } \\
\text { systems, centralize remote customer service processes, and deploy feedback }\end{array}$ \\
\hline & $\begin{array}{l}\text { Relations with } \\
\text { suppliers }\end{array}$ & Collaborating with suppliers to create new services and products \\
\hline & Production orders & $\begin{array}{l}\text { Funds for increasing consumer growth, contracts for information technology } \\
\text { infrastructure maintenance, preparing a feasibility study }\end{array}$ \\
\hline $\begin{array}{l}\text { Artistic- } \\
\text { related }\end{array}$ & $\begin{array}{l}\text { Books and music } \\
\text { pieces }\end{array}$ & Funds for publications on employee communication \\
\hline
\end{tabular}

Source: NASDAQ OMX Baltic biržos interneto tinklalapis: http://www.nasdaqomxbaltic.com/

The weight assigned to the element of nonfinancial information on the intangible assets is calculated and expressed as a percentage:

$$
\begin{aligned}
\sum X_{i t}=a_{1}+a_{2} \ldots \ldots . a_{n} ; \sum n_{i t}=X_{1}+X_{2} \ldots \ldots \ldots X_{n} ; & \\
N I N T E_{i t} & =\frac{\sum X_{i t}}{\sum n_{i t}} \times 100 \%
\end{aligned}
$$

Where:

NINTE $_{i t}$ the number of elements of nonfinancial information on intangible assets at the end of the accounting year, $\%$

$\sum X_{i t} \quad$ the total amount of the unit of elements of the company at the end of the accounting year; $a_{1}+a_{2} \ldots \ldots . a_{n}-$ the number of the unit of sub-elements of the company at the end of the accounting year; 
$X_{1}+X_{2} \ldots \ldots \ldots X_{n}$ the number of the unit of elements of the company at the end of the accounting year

$\sum n_{i t} \quad$ the total amount of elements at the end of the accounting year.

Calculation of nonfinancial information on the intangible assets:

$$
\begin{gathered}
N I N T E V_{i t}=N I N T_{i t} \times N I N T E_{i t} \\
N I N T_{i t}=\frac{R V_{i t}}{N K_{i t}} \times F I N T_{i t}
\end{gathered}
$$

Where:

NINTEV $V_{i t}$ the value of the elements of nonfinancial information on intangible assets at the end of the accounting year, (eur)

$N I N T_{i t} \quad$ the value of the elements of nonfinancial information on intangible assets of the company at the end of the accounting year, (eur)

$R V_{i t} \quad$ the market value of the company at the end of the accounting year, (eur)

$N K_{i t} \quad$ the value of owner' equity in the company at the end of the accounting year, (eur)

FINT $_{i t}$ the value of financial information on intangible assets of the company at the end of the accounting year, Eur

NINTE $_{i t}$ the number of elements of nonfinancial information on intangible assets at the end of the accounting year, $\%$

The three-step methodology proposed by R. Lyn and J. M. Morse (2007) was taken into account in the development of the common coding system: 1. Descriptive coding - it identifies actual information about a particular piece of text; 2. Business Encoding - it separates text segments and gives them an abstract name related to something; 3. Analytical Encoding - it develops and systematizes the coding and categories system, looks for links and interfaces. Adaptation of the coding system is one of the most complex stages of the formation of the nonfinancial intangible asset components.

Stage 2. The determination of elements of general intangible assets. Based on the International Accounting Standards classification of financial information on the intangible assets includes 6 elements: marketing, contract, technology, innovative, customer and goodwill. After analysis of other financial reports of the companies, we determine that the nonfinancial information on the intangible assets includes 7 elements: marketing, human, contract, technology, innovative, customer, artistic. The difference between financial and nonfinancial information groups is that the elements accounted for by intangible assets include 11 accountable subelements and 46 nonaccountable subelements. After merging of these parts, there were selected 57 subelements of intangible assets, which are grouped into 8 main elements of general intangible assets (Table 5).

Table 5: Elements for measuring the structure of general intangible assets

\begin{tabular}{|l|l|}
\hline Elements & Subelements \\
\hline Marketing-related & $\begin{array}{l}\text { Companies signs, news headlines, non-competition agreements, trademarks (names), website } \\
\text { addresses }\end{array}$ \\
\hline Human-centered & $\begin{array}{l}\text { Wage, individual expertise, skills, experience, education, innovation, employee competence, } \\
\text { motivation, loyalty, training }\end{array}$ \\
\hline
\end{tabular}




\begin{tabular}{|l|l|}
\hline Contract-based & $\begin{array}{l}\text { Advertising, delivery and supply contracts, building permits, patents, contractual rights: design, } \\
\text { copyright (royalty), company law, etc., franchise, licenses }\end{array}$ \\
\hline Technology-based & $\begin{array}{l}\text { Technology patents, trade secrets, such as secret formulas, software, databases, including } \\
\text { equipment }\end{array}$ \\
\hline Innovative-related & $\begin{array}{l}\text { Research and development, scientific and technological research and development, exploration of } \\
\text { minerals, development of new products, new architecture and engineering design, brand } \\
\text { marketing, market research, external development consultancy, organizational structure, creative } \\
\text { capital, manufacturing technology (processes), data, publications, strategy, business culture, } \\
\text { organization routines and procedures, market and competitive insights, development costs for } \\
\text { intangible assets: design, construction and testing of models and models prior to the start of } \\
\text { production; designing instruments, tool samples, shapes and prints based on new technologies; } \\
\text { design, construction and operation of equipment for the production of pilot samples, design, } \\
\text { construction and testing of selected new materials, equipment, products, processes, systems or } \\
\text { services }\end{array}$ \\
\hline Customer-related & $\begin{array}{l}\text { Buyer lists, non-contractual customer relations, customer retention, customer profitability, } \\
\text { relationships (contracts) with suppliers, product orders and agreements (cooperation agreements), } \\
\text { customer contracts and their relationship }\end{array}$ \\
\hline Geodwill & $\begin{array}{l}\text { Books, newspapers, magazines and other literary works, musical compositions: lyrics and } \\
\text { commercials, paintings and photographs, audiovisual material, including motion pictures or films, } \\
\text { music videos and television programs }\end{array}$ \\
\hline Artistic-related &
\end{tabular}

Source: Hendriksen and Van Breda (1992); Brooking (1996); Sveiby (1997); Mortensen at el. (1997); Stewart (1997); Bontis (1999); Mikuleniené and Jucevičius (2000); Kayo (2002); Wyatt and Abernethy (2003); Guthrie, Petty, Yungvanich, Ricceri (2003); Goran at el. (2005); Corrado at el. (2005); Lin and Tang (2009); KPMG AG (2010); Pekkola (2011); Ramanauskaitè (2012); OECD (2013), Sacui and Szatmary (2015); Ifeanyi and Caroline (2016); Ocak and Findik (2019); Vanini and Rieg (2019).

Marketing-related assets reflect economic information about market support and its development: trademarks, names, customer portfolio, web sites, trading styles, and so on. Human-centered assets include employee knowledge, skills, experience, training, payroll, and other resources needed to maintain employee motivation and loyalty. Contract-based assets are important for the protection and control of copyrights, licenses, patents, projects and other resources. Technology-based assets include computer programs, hardware, databases, technology patents, and more. The high turnover of intangible resources dominates in the Innovative-related assets. These resources reflect the company's investment goals and their solutions. These assets include development and research costs, scientific and technological research, development of new products, development, market research, organizational structure, business culture, etc. Customer-related assets reveal the potential of buyers and suppliers, their cooperative relationships, agreements, and so on. Artistic-related assets show creative production distribution: books, newspapers, musical works, promotional films, paintings, photographs, video films, etc. Goodwill is recognized when an enterprise acquires another entity in the hope and future of economic benefits. This element includes the reputation, image, business culture, loyalty and other resources of the acquired company. The review of the classification of intangible assets shows a set of intangible assets that increase the value added by companies and the current level of competition in the market. Each element of an intangible asset includes different subelements. The latter shows the economic benefits of each element of this asset.

After analysis of the methodology of financial and nonfinancial information on the intangible assets, we can notice, that the structure of intangible assets differs from international and general accounting standards regulating financial accounting. The main elements of financial and nonfinancial information on the intangible assets are related to marketing, contract-based, innovative, technology-based, human-centered, customer, artistic and goodwill. Each element of an intangible asset includes different subelements. We discover that some elements of financial information are recorded as intangible assets in the 
balance sheet, but most elements of nonfinancial information are written off as operating expenses in the income statement. It happened for legislation governing the accounting for intangible assets limits the accounting for these assets, as it is necessary by the law to justify the economic benefits, to establish a fair value and to ensure control of the intangible asset. The value of financial information on the intangible asset is easier to determine because the international and general accounting principles refer to only two valuation methods - cost and revaluation. But the valuation of the value of nonfinancial information on the intangible assets to measure is a complicated procedure in the practice. However, the most difficult to determine the future economic benefits and to control its economic benefits of the intangible assets, as the evaluation process is long and confusing.

\section{Results}

Analyzing the structure of financial information on the intangible assets (FINT), we determined that the most Lithuanian companies in their activity using elements related to subelements of technologies, contracts, and other assets. This includes most of the financial information on the intangible assets in the Lithuanian companies. A little less was included assets of marketing, customer-related and goodwill. As expected, innovative assets in the balance sheet are recognized and recognized very rarely. In figure 1 we can see how the elements of the asset group changed, their recognition and accounting in the balance sheet at the end of 2019-2015 years. The largest share of FINT was in customer-related, contractrelated assets, goodwill and it remained the same throughout the survey period, except for 2015. Other elements of FINT, irrespective of the fact that the general accounting standards limit their recognition in the accounts, have been steadily increasing and maintaining a constant level. The smallest part of the structure of FINT consisted of marketing-related and innovative-related assets. The study shows that the highest growth in the structure of FINT was attributable to contract-based assets (23,8 percentage points (p.p.)).

Figure 1: Structure of financial information on the intangible assets of Lithuanian's Companies 2009-2015 (\%)

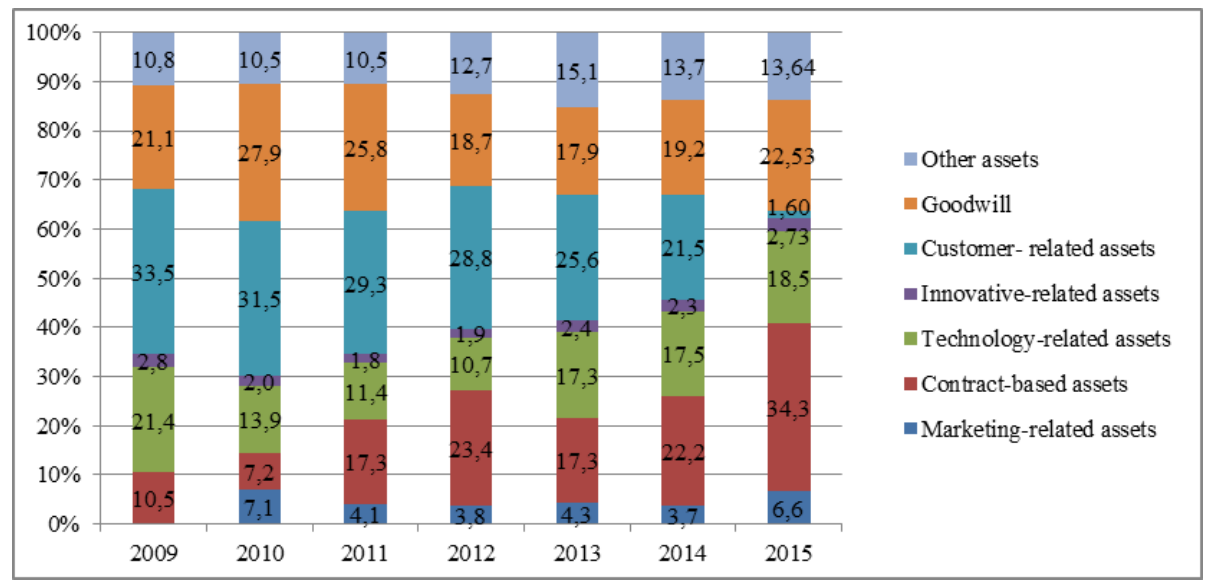

Source: own processing

The largest decrease was observed in customer-related assets (31,9 p.p.). It should be noted, the formation of FINT depends on the recognition of intangibles (subelements), their accounting and the accuracy of the information provided on the intangible assets in the balance sheet. Most subelements of FINT are not recognized and accounted for as intangible assets in accounting. The value of FINT does not reflect the true value of the asset, which is 
prevalent in the market, although the company can revalue the asset in accounting. The general accounting standards do not oblige companies to revalue assets, they may choose to revalue assets or not.

The disclosure of components of financial information on the intangible assets (FINT) of Lithuanias' companies contains a detailed analysis of the subelements of these assets (Table $6)$.

Table 6: Subelements of financial information on the intangible assets of Lithuanian's Companies

\begin{tabular}{|l|l|l|}
\hline Effect & Elements & Subelements \\
\hline \multirow{3}{*}{ THE BIGGEST PART OF FINT } & TECHNOLOGY-BASED & Software \\
\cline { 2 - 3 } & OTHER ASSETS & $\begin{array}{l}\text { Unfinished projects; Used fully amortized } \\
\text { assets in the company's activities; } \\
\text { Creating assets and others. }\end{array}$ \\
\cline { 2 - 3 } & CONTRACT-BASED & $\begin{array}{l}\text { Patents, contractual rights: design, } \\
\text { royalties, company rights, licenses }\end{array}$ \\
\cline { 2 - 3 } & CUSTOMER-RELATED & $\begin{array}{l}\text { Customer contacts and related customer } \\
\text { relationships }\end{array}$ \\
\hline \multirow{2}{*}{ THE SMALLEST PART OF FINT } & GOODWILL & $\begin{array}{l}\text { Reputation / organization's image } \\
\text { Brands, trademarks, company name }\end{array}$ \\
\cline { 2 - 3 } & MARKETING-RELATED & $\begin{array}{l}\text { Expenditure on development: design, } \\
\text { construction, and testing of samples and } \\
\text { models }\end{array}$ \\
\hline
\end{tabular}

The most of FINT structures consisted of sub-elements related to the acquisition of software, the implementation of unfinished projects, assets that were fully amortized but still used in the company's activities, corporate rights, patents, licenses, reputations, etc. One of the most important elements of the property is goodwill. The value of goodwill as assets depends on transactions between companies, their mergers, and acquisitions. Practical experience in business, reputation, image, clients, brands, etc., acquired by other companies, also plays an important position in FINT structure. Another important asset element is a customer-related asset. This type of asset increased the volume of FINT when contracts were concluded with customers and suppliers of Lithuanian or foreign companies. The smallest part of this asset was made up of marketing and innovative assets. Trademarks, company names, development costs are resources that relate to the company's ability to exploit the growth potential of the market.

Not all subelements of FINT are accounted for in the balance sheet of Lithuanian companies. No information found on the following subelements of FINT: website addresses, contractual rights: design, copyright (royalties); franchise; designing of database, including hardware, tool examples, forms and prints according to new technologies; equipment for the production, design, construction and operation of samples; design, construction and testing of selected new alternative materials, equipment, products, processes, systems or services. The reasons, which led to the low recognition of FINT' subelements in intangible assets may be different: overly complex accounting aspects in recognizing assets in the balance sheet or unwillingness to disclose information on competition in the market, etc. Hence, the full potential has not yet been realized and the structure of FINT does not fully reflect the intangible assets managed by Lithuanian companies. To exploit the full potential of FINT and avoid losses due to insider information, alternative solutions need to be adopted and the level of intangible assets increased. It is therefore proposed to adjust the way of calculating the value of intangible assets for nonfinancial information.

Scientists who analyzed the impact of FINT's value on the company's market value found that FINT's value is strictly governed by International Accounting Principles, and therefore accounts for a small proportion of total assets in companies (Table 7). 
Table 7: The proportion of the structure of financial information on total intangible assets, \%

\begin{tabular}{|l|l|l|l|l|l|l|l|}
\hline Companies & $\mathbf{2 0 0 9}$ & $\mathbf{2 0 1 0}$ & $\mathbf{2 0 1 1}$ & $\mathbf{2 0 1 2}$ & $\mathbf{2 0 1 3}$ & $\mathbf{2 0 1 4}$ & $\mathbf{2 0 1 5}$ \\
\hline Telia Lietuva & 4.2 & 5.1 & 4.6 & 4.4 & 5.1 & 5.5 & 5.8 \\
\hline Lietuvos dujos* & 0.4 & 0.4 & 0.3 & 0.2 & 0.7 & 0.7 & ND \\
\hline Lesto* & 0.4 & 0.2 & 0.1 & 0.2 & 0.2 & 0.4 & ND \\
\hline Lietuvos energijos gamyba** & ND & ND & 1.1 & 1.8 & 1.1 & 1.2 & 2.0 \\
\hline City Service & $\mathbf{4 1 . 2}$ & $\mathbf{4 1 . 2}$ & $\mathbf{4 4 . 3}$ & $\mathbf{3 1 . 3}$ & $\mathbf{1 9 . 3}$ & $\mathbf{1 9 . 7}$ & $\mathbf{1 0 . 5}$ \\
\hline Klaipėdos nafta & 0.04 & 0.1 & 0.2 & 0.4 & 0.2 & 0.3 & 0.04 \\
\hline Vilniaus degtinė** & $\mathbf{N D}$ & $\mathbf{1 8 . 8}$ & $\mathbf{1 1 . 2}$ & $\mathbf{1 2 . 2}$ & $\mathbf{1 4 . 0}$ & $\mathbf{1 1 . 9}$ & $\mathbf{1 0 . 4}$ \\
\hline Pieno žvaigždės & 1.4 & 1.6 & 1.2 & 1.5 & 0.9 & 1.0 & 0.1 \\
\hline Panevěžio statybos trestas & 1.1 & 0.6 & 0.1 & 0.2 & 0.3 & 0.2 & 0.3 \\
\hline Dvarčionių keramika & 0.1 & 0.04 & 0.01 & 0.01 & 0.01 & 0.0 & 12.3 \\
\hline Vilniaus baldai & 3.2 & 2.2 & 0.3 & 0.2 & 0.8 & 1.2 & 1.3 \\
\hline Snaigė & $\mathbf{1 7 . 8}$ & $\mathbf{1 9 . 1}$ & $\mathbf{2 4 . 3}$ & $\mathbf{2 6 . 8}$ & $\mathbf{2 5 . 5}$ & $\mathbf{1 5 . 2}$ & $\mathbf{5 . 7}$ \\
\hline Invalda INVL & 2.1 & 2.8 & 3.9 & 3.8 & 3.6 & 10.7 & 8.8 \\
\hline Šiaulių bankas & 0.02 & 0.3 & 0.04 & 0.1 & 0.04 & 0.2 & 0.2 \\
\hline Rokiškio sūris & 0.7 & 0.2 & 0.3 & 0.3 & 0.2 & 0.2 & 0.01 \\
\hline Kauno energija & 0.1 & 0.1 & 0.1 & 0.05 & 0.1 & 1.0 & 1.0 \\
\hline Grigeo Grigiškès & 2.6 & 1.4 & 1.8 & 2.5 & 2.3 & 1.8 & 1.3 \\
\hline Apranga & 1.0 & 0.9 & 0.6 & 0.3 & 0.8 & 1.1 & 1.0 \\
\hline Source: & & & & & & \\
\hline
\end{tabular}

Source: own processing

Note: 0.0 - no assets found; ND - no data available: * Lietuvos Dujos and Lesto - no data for 2015, therefore data are provided by 2014. ** Lietuvos energija - no data available for 2009 and 2010, therefore data are available from 2011 onwards. *** Vilniaus degtine - no data available for 2009, therefore data are available from 2010.

The results of the survey showed that the average share of FINT, compared to the total assets of the companies, was in the following companies: City service (29.6\%), Vilniaus degtine $(13.1 \%)$, Snaige $(19.2 \%)$, Invalda INVL (5.1\%) and Telia Lietuva (5.0 \%). The proportion of FINT of other Lithuanian companies accounted for a minor part of the total asset structure. The problem is that the value of FINT is determined by the historical price, which is often different in the market from the real asset value. It can be noticed that the value of FINT usually amounts to less than 5 per cent. part of the total asset structure. Accounting for FINT in the balance sheet may not always be related to the limited application of accounting standards for the recognition of such assets in accounting. The proportion of FINT in the total asset structure may also be lower for other reasons: FINT's perception of the value of the company is underestimated, managers do not see the value of revaluing assets at market value, confusing asset valuation methodology, etc.

To identify the components of nonfinancial information on the intangible assets were used the content analysis method and the nonfinancial information coding system (Table 8). The disclosure of components of nonfinancial information on the intangible assets (NINT) of Lithuania's companies contains a detailed analysis of the subelements of these assets (Table 8).

Table 8: Subelements of nonfinancial information on the intangible assets of Lithuanian's Companies

\begin{tabular}{|l|l|l|}
\hline \multirow{2}{*}{ Elements } & Subelements & THE SMALLEST PART OF NINT \\
\hline HUMAN-CENTERED & THE BIGGEST PART OF NINT & $\begin{array}{l}\text { Individual expert knowledge skills, experience, } \\
\text { novelty, employee competence, motivation, } \\
\text { loyalty }\end{array}$ \\
\hline INNOVATIVE- RELATED & $\begin{array}{l}\text { Creative capital } \\
\text { Organizational (business) structure } \\
\text { (culture) } \\
\text { Strategy } \\
\text { Market and Competitiveness Insights } \\
\text { Production orders }\end{array}$ & $\begin{array}{l}\text { External development consultancy, data, } \\
\text { publications, culture, organization routines and } \\
\text { procedures, buyer lists, brand marketing, } \\
\text { development of new products, research and } \\
\text { development costs, scientific and technological } \\
\text { research and development }\end{array}$ \\
\hline
\end{tabular}




\begin{tabular}{|l|l|l|}
\hline & and market research & \\
\hline CONTRACT - BASED & Advertising & $\begin{array}{l}\text { Delivery and supply contract, constructions } \\
\text { permits }\end{array}$ \\
\hline CUSTOMER - RELATED & $\begin{array}{l}\text { Customer retention } \\
\text { Non-contractual customer } \\
\text { Technology patenting } \\
\text { suppliers }\end{array}$ \\
\hline MARKNOLOGY & \\
\hline ARTISTIC - RELATED & Books, musical compositions \\
\hline
\end{tabular}

Source: own processing

The biggest part of the structure of nonfinancial information on intangible assets has been elements there included innovative-related, human-centered and customer-related assets. The smallest part of the structure of nonfinancial information on intangible assets applied elements of technology-based, contract-based and marketing-related assets. Artistic-related assets are only found in one company. Human-centered assets include subelements that are based on the relationship between the employee and the company. Wages, education, experience, motivation, competence - are the resources on which the company's prosperity and future depend. Innovative assets relate to: 1) the development, updating and upgrading of new products; 2) development of creative capital, modernization of technological processes; 3) strengthening competitiveness; 4) the growth of the company's value, etc. This type of asset consisted of the following main subelements: creative capital, the organizational structure of the business, strategy, market and competitiveness insights, the growth of which is associated with the implementation of innovative processes. However, research and development and research/development activities included a small proportion of innovative assets. The customer retention subelement dominated the customer-related asset. Non-contractual customer relations, relations with suppliers, production orders and agreements constituted a smaller part of intangible assets of non-financial information. The value of advertisements was highlighted in the contract-based asset and this subelement remained at a similar level throughout the period under investigation. Technology patents are most distinguished in technology-based assets. Trademarks dominated in the marketing-related assets. A small part was found in artistic assets, only books, and music.

Analyzing the elements of nonfinancial information on intangible assets (NINT), it can notice the changed of this asset structure during the period (Figure 2). Innovative-related assets were the most significant (average value (a.v.) $47 \%$ ), human-centered (a.v. $30 \%$ ) and customer-related assets (a.v. $15 \%$ ). Comparing these received data with the structure of FINT can be confirmed that innovative assets were account for only a small proportion of FINT and human-centered assets were not fully accounted for, but the assets of the customer-based were ranked higher than the structure of FINT. Unlike the structure of FINT, technology-related, contract-base and marketing-related assets represent only a small part of the NINT structure, and artistic-related assets accounted particularly rarely. The results of the study show that the structure of NINT differs significantly from the structure of FINT. 
Figure 2: Structure of nonfinancial information on the intangible assets of Lithuanian's Companies 2009-2015 (\%)

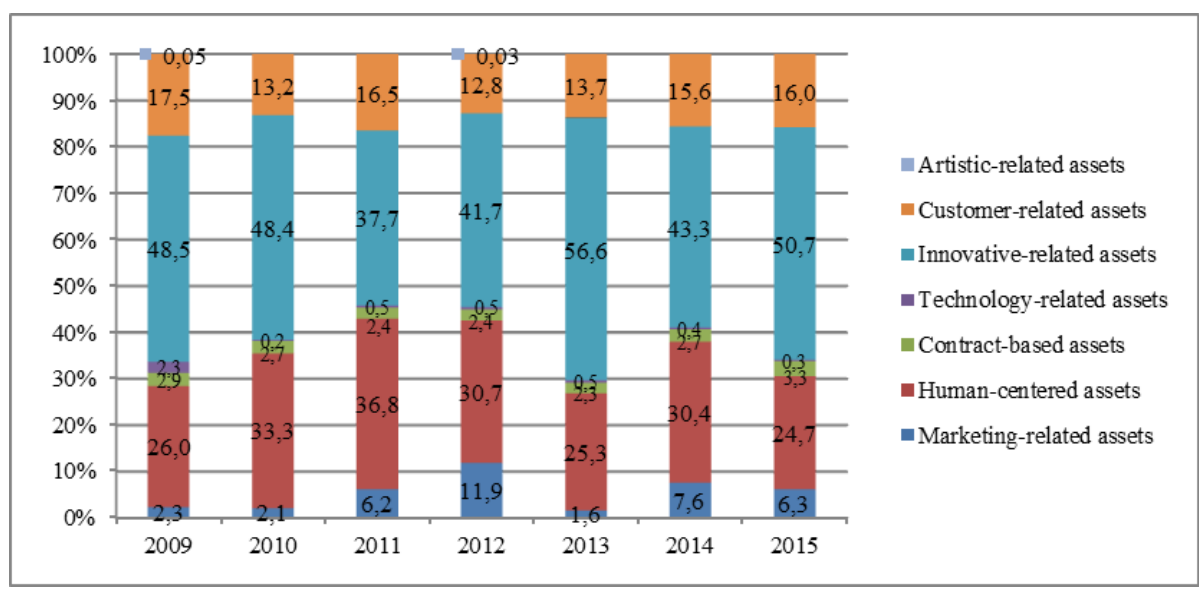

Source: own processing

Analyzing the proportion of NINT is the total asset structure, it was noted that the percentage of the proportion of NINT is much higher than the proportion of FINT in the structure of total assets (Table 9). The results of the survey showed what the average proportion of NINT to the total assets of the companies was in the following companies: City Service (a.v. $40 \%$ ), Snaige (a.v. $28.8 \%$ ), Vilniaus degtinè (a.v. $8.9 \%$.), Teo (a.v. $9.9 \%$ ) and Invalda INVL (a.v. $5.0 \%$ ).

Table 9: The proportion of structure of nonfinancial information on total intangible assets, \%

\begin{tabular}{|c|c|c|c|c|c|c|c|}
\hline Companies & 2009 & 2010 & 2011 & 2012 & 2013 & 2014 & 2015 \\
\hline Telia Lietuva & 6.1 & 9.5 & 7.2 & 8.6 & 10.1 & 13.2 & 14.5 \\
\hline Lietuvos dujos* & 0.2 & 0.2 & 0.2 & 0.1 & 0.8 & 0.8 & ND \\
\hline Lesto* & 0.1 & 0.1 & 0.05 & 0.1 & 0.1 & 0.6 & ND \\
\hline Lietuvos energijos gamyba** & ND & ND & 0.5 & 1.1 & 0.7 & 1.6 & 2.5 \\
\hline City Service & 70.1 & 80.3 & 53.2 & 34.4 & 18.0 & 16.0 & 7.7 \\
\hline Klaipèdos nafta & 0.03 & 0.2 & 0.2 & 0.3 & 0.2 & 0.2 & 0.0 \\
\hline Vilniaus degtine $\dot{e}^{* * *}$ & ND & 9.4 & 5.9 & 7.1 & 14.2 & 10.1 & 6.6 \\
\hline Pieno žvaigždès & 1.5 & 3.0 & 2.6 & 3.1 & 2.2 & 1.9 & 0.3 \\
\hline Panevėžio statybos trestas & 0.7 & 0.6 & 0.1 & 0.1 & 0.1 & 0.1 & 0.1 \\
\hline Dvarčionių keramika & 0.1 & 0.01 & 0.003 & 0.004 & 0.001 & 0.0 & 1.4 \\
\hline Vilniaus baldai & 2.5 & 3.8 & 0.7 & 0.4 & 2.8 & 7.6 & 6.1 \\
\hline Snaigè & 7.4 & 13.4 & 48.9 & 48.0 & 48.9 & 27.8 & 7.3 \\
\hline Invalda INVL & 1.8 & 5.0 & 3.3 & 3.2 & 4.9 & 8.8 & 7.4 \\
\hline Šiaulių bankas & 0.04 & 0.2 & 0.03 & 0.03 & 0.03 & 0.1 & 0.2 \\
\hline Rokiškio sūris & 0.5 & 0.3 & 0.2 & 0.2 & 0.1 & 0.1 & 0.01 \\
\hline Kauno energija & 0.04 & 0.02 & 0.01 & 0.01 & 0.01 & 0.1 & 0.1 \\
\hline Grigeo Grigiškès & 6.1 & 2.5 & 1.7 & 2.7 & 2.9 & 2.8 & 2.0 \\
\hline Apranga & 5.3 & 4.1 & 2.1 & 0.7 & 2.2 & 1.1 & 2.9 \\
\hline
\end{tabular}

Source: own processing

Note: 0.0 - no assets found; ND - no data available: * Lietuvos Dujos and Lesto - no data for 2015, therefore data are provided by 2014. ** Lietuvos energija - no data available for 2009 and 2010, therefore data are available from 2011 onwards. *** Vilniaus degtine - no data available for 2009, therefore data are available from 2010.

The proportion of NINT of other companies averaged 0,1 to 3 per cent. Hence, the larger part of the intangible assets of these companies is not recorded in the balance sheet. In the determination of the general structure of intangible assets (BNT), the structure of these assets was analyzed in Lithuanian companies (Figure 3). Analyzing the structure of general 
intangible assets, the high distribution of the structural part of the innovative-related assets (a.v. $27.4 \%$ ) is identified, and in others, the ratio of customer-related and human-centered assets was less ((a.v.) $19.2 \%$ and 16.0 respectively).

Figure 3: Structure of general intangible assets of Lithuanian's Companies 2009-2015,\%

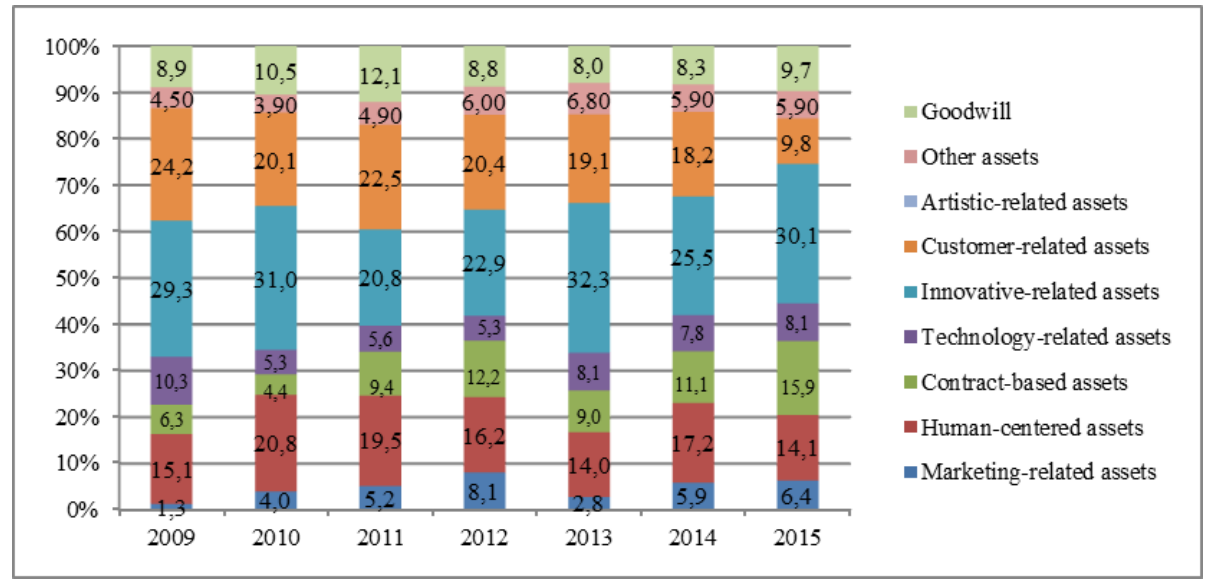

Source: own processing

A smaller part of the structure on this kind of intangible asset can be attributed to contractrelated assets, goodwill and technology-related assets, with volumes ranging from 9.8 to 7.2 per cent on average. Marketing-related assets and other assets included about 4.8 to 5.4 per cent, artistic-related assets were about 0.01 per cent. The contract-based assets ( 9.6 p.p.) and marketing-related assets (5.1 p.p.) contributed most to the growth of the overall intangible asset structure. Slightly less - innovative-related assets (0.8 p.p.), other assets (1.4 p.p.) and goodwill (0.8 p.p.). In 2015, the declines in general intangible assets were driven by customer-related assets (14.4 p.p.), human-related assets (1.0 p.p.) and technology-related assets (2.2 p.p.).

The results of the study showed, in most cases, the acquisition costs of assets that are not recognized as intangible assets are either included in the cost of production or recognized as operating expenses. By applying this accounting method, companies have a positive effect on the lower taxable value in terms of corporation tax. However, this provides a short-term effect as not only the quality of accounting information will decrease in the long run but also the ownership of the owners in publicly available financial statements. According to Aboody and Lev (2000), if there are indications that financial statements in the public domain lack information about intangible assets, the information provided is not fully disclosed. This leads to incorrect valuation of intangible assets and an inadequate specification of valuation models. Dužinskas and Jurgelevičius (2014) are convinced that investments in intangible assets explain up to $50 \%$ labor productivity and have a positive impact on overall productivity levels. If the cost of intangible assets were properly accounted for in the company and national accounts, GDP growth rates in the European Union would increase by an average of $5 \%$. Companies need to disclose key investor information to attract more capital. Disclosure of information about intangible assets provides a more comprehensive picture of the company for external users - then investors see not only financial performance indicators, but also the company's potential: employees, relationships with customers, suppliers, and so on. 


\section{Discussion}

Based on the results obtained, and intangible assets classification has been compiled incorporating eight elements of intangible assets that are distinguished from many other proposed ones, since they show different sub-elements of intangible assets of financial and non-financial information, linking them to investing in people, market research, intellectual property, technologies, innovations, relationships, etc. This classification can be successfully applied in different branches of enterprises, to expand and supplement the theoretical and practical concepts of the company's financial management. The structure intangible assets measurement information may be valuable to both the owners of the company and investors, as value intangible assets play an important practical role in assessing the business value.

\section{Conclusion}

The formation of the structure of intangible assets, taking into account the legal regulation of these assets in accounting, focuses on eight main elements of intangible assets: marketingrelated, human-centered, contract-based, technology-based, innovative-related, customerrelated, artistic-related and goodwill. The determination of the structure financial information on the intangible assets (FINT) identifies the structural changes of these assets, to mark the most significant asset elements and their subelements, to assess the proportion of structure" FINT in the total asset. The results of the study showed that the structure of elements of the financial information on the intangible assets is not fully disclosed in the balance sheet. This is confirmed by the results of the survey, which shows that the proportion of FINT in Lithuanian's companies is less than $5 \%$ of the total assets. It is clear that the value of FINT, which is disclosed publicly in the balance sheet, is limited. This presupposes that publicly available information on the value of FINT in the balance sheet of Lithuanian companies is inaccurate and that the components of that asset are inseparable from the application of general accounting standards. To increase investor confidence in the company, it is necessary to increase the transparency of information in the capital market. However, as the analysis has shown, it cannot be said unconditionally that FINT's accounting is limited by general accounting principles, as other reasons limit the recognition of FINT and its accounting in the balance sheet.

The customized content analysis method allowed the identification of elements of nonfinancial information on the intangible assets (NINT). The determination of the structure NINT has shown that the structure of general intangible assets is particularly important in demonstrating the true value of an intangible asset in an entity. It was established that Lithuanian companies have a larger proportion of NINT than publicly disclosed by the FINT structure. Most of the information has been found on innovative-related, customer-related and human-centered assets. This shows that these asset elements occupy a leading position in the company's business. Although it is difficult to quantify the economic benefits of NINT, there is no doubt that these assets can provide added value. Choosing the right value for NINT is the right choice of method that reflects the market rather than the historical price. Choosing the right method makes it possible to increase the value of disposable assets in companies. It can be acknowledged that Lithuanian companies face more diverse types of intangible assets than shown in the balance sheet. The problem is obvious because intangibles of NINT cannot be accounted for or presented in the balance sheet. However, this information can be disclosed by companies in other annual reports, thus increasing the transparency of information about the intangibles used in the company's operations. 


\section{References}

Aboody, D. \& Lev, B. (2000). Information asymmetry, R\&D and insider gains. Journal of Finance, 2,747-2,766.

Ahn, Y. (2019). Intangible capital, volatility shock, and the value premium. Financial Review, 54(4) 739-762.

Banker, R.D., Huang, R., Natarajan, R. \& Zhao, S. (2019). Market valuation of intangible asset: Evidence on sg\&a expenditure. The Accounting Review, 94(6), 61-90.

Bontis, N. \& Dragonetti N.C., et. al. (1999). The knowledge toolbox: A review of the tools available to measure and manage intangible resources. European Management Journal, $17,391-401$.

Bontis, N. (1998). Intellectual capital: An exploratory study that develops measures and models. Management Decision, 36(2), 63-76.

Corrado, C., Hulten, C. \& Sichel, D. (2005). Measuring capital and technology: expanded framework. Measuring Capital in the New Economy, National Bureau of Economic Research Studies in Income and Wealth, 65, 11-45. Chicago, IL: The University of Chicago Press.

Crema, M. \& Nosella, A. (2014). Intangible assets management and evaluation: evidence from SMEs. Engineering Management Journal, 26 (1), 8-14.

Dužinskas, R. \& Jurgelevičius, A. (2014). Nematerialaus turto samprata: ištakos, apibrěžimai, savybės ir elementai. Business Systems and Economics, 4(2), 204-216.

Ferdaous, J. \& Rahman, M. (2019). The effects of intangible assets on firm performance: An empirical investigation on selective listed manufacturing firms in DSE, Bangladesh. American Journal of Business, 34(3/4), 148-168.

Goran, R. \& Pike, S. Et al. (2005). Managing Intellectual Capital in Practice. Amsterdam: Heidelberg, 384.

Guthrie, J. \& Petty, R. Et al. (2003). Intellectual capital reporting: Content approaches to data collection. Paper presented at Performance Measurement Association Intellectual Capital Symposium, Cranfield.

Ifeanyi, N. \& Caroline, O. (2016). Evaluating the effect of intangible assets on economic value added of selected manufacturing firms in nigeria. European Journal of Business and Management, 8(15).

Jaara, O.O. \& Elkotayni, K.A.R. (2016). The impact of intangible assets internally developed on the market values of companies. „A field study in the pharmaceutical companies in Jordan“. Accounting and Finance Research, 5(2), 154-163.

Januškevičius, R. \& Januškevičienè, O. (2006). Elementarusis Tikimybiu ir Statistikos Kursas Informatikams. Vilniaus Pedagoginis Universitetas, 20-21.

Jukaitytė-Sungailienè, A. (2009). Turto samprata Lietuvos civilinèje teisèje. Socialinių Mokslų Studijos, 3(3), 213-227.

Kayo, E.K. (2002). Capital structure and risk of tangible and intangible-intensive companies: A contribution of studying of firm valuation. PhD Dissertation, University of Sao Paulo.

Kasiulevičius, V. \& Denapiene, G. (2008). Statistikos taikymas mokslinių tyrimu analizejje. Gerontologija: Teorija ir Praktika. 9(3). 176-180.

Kimouche, R. \& Rouabhi, A., et.al. (2016). The impact of intangibles on the value relevance of accounting information: Evidence from french companies. Intangible Capital. 12(2), 506-529.

Krippendorff, K. (2013). Content Analysis: An Introduction to its Methodology. The Annenberg School for Comunication University of Pennsylvania.

Kisgern, DJ., Qian, J. \& Song, W. (2009). Are fairness opinions fair? The case of mergers ans acquisitions. Journal of Financial Economics, 91(2), 179-207.

Lev, B. (2003). Intangibles: Management, Measurement, and Reporting, CwintoConsalting, Moscow.

Lev, B. \& Daum, J. (2004), The dominance of intangible assets: consequences for enterprise management and corporate reporting. Measuring Business Excellence, 8(1), 6-17.

Lin, G.T.R. \& Tang, J.Y.H. (2009). Appraising intangible assets from the viewpoint of value drivers. Journal of Business Ethics, 88(4), 679-689.

Lyn, R. \& Morse, J.M. (2007). Readme First for a User's Guide to Qualitative Methods. 2nd ed. Thousand Oaks, London, New Delhi: SAGE Publications. 
Lönnqvist, A. \& Mettänen, P. (2002). Criteria of sound intellectual capital measures. Proceedings of the 2nd international workshop on performance measurement, Hanover, 6-7.

Mačerinskienè, I. \& Survilaitè, S. (2011). İmonès pridètinès vertè ir jos intelektinio kapitalo sąsaja. Verslas: Teorija ir Praktika, 12(2),183-192.

Mikulėnienè, R. \& Jucevičius, R. (2000). Organizacijos Intelektinis Kapitalas: Sandaros ir Pagrindiniu Savoku Interpretacijos. Socialiniai Mokslai: Kaunas, 3(24), 65-76.

Ocak, M. \& Findik, D. (2019). The impact of intangible assets and sub-components of intangible assets on sustainable growth and firm value: Evidence from Turkish listed firms. Sustainability, 11(19), 1-23.

OECD, (2013). Supporting Investment in Knowledge Capital, Growth and Innovation. OECD Publishing.

Perli, R. \& Sakellaris, P. (1998). Human capital formation and business cycle persistence. Journal of Monetary Economics, 42(1), 67-92.

Pekkola, H. (2011). Intangible capital - driver of growth in Europe. Proceedings of the University of Vaasa.

Ramanauskaite, A. (2012). Intelektinio kapitalo interpretacija šiuolaikinès rinkos sąlygomis: teorinis tyrimas. Apskaita, Auditas, Analizè: Mokslas Inovacijų ir Globalizacijos Kontekste, 572-581.

Rider, E.A., Comeau, M., Truog, R.D., Boyer \& Elaine, C.K. (2019) Identifying intangible assets in interprofessional healthcare organizations: Feasibility of an asset inventory. Journal of Interprofessional Care, 33(5), 583-586.

Rodov, I. \& Leliaert, P. (2002). FiMIAM: Financial method of intangible assets measurement. Journal of Intellectual Capital: Measuring Intellectual Capitalism. 3(3), 323-336.

Rudžionienè, K. \& Ramanauskaitè, A. (2012). Intelektinio kapitalo pripažinimas ir ịvertinimas finansinèje apskaitoje. Apskaita, Auditas, Analizè: Mokslas Inovaciju ir Globalizacijos Kontekste, 628-637.

Sacui, V. \& Szatmary, M.C. (2015). Intangible assets in business combinations. Review of Internation al Comparative Management, 16(3), 385-397.

Schwarze, J. (1993). Grundlagen der Statistik 2. 5th edition; Herne/Berlin: Neue Wirtschaftsbriefe.

Shah, T. \& Khedkar, A. (2006). Measuring intangible assets - Indian experience. Indian Institute of Planning and Management (IIPM) Ahmedabad, 1-23.

Sofian, S. \& Zaleha, S. et. al. (2011). Effect of recognition of intellectual capital on relevance of accounting information. Interdisciplinary Journal of Contemporary Research in Business Institute of Interdisciplinary Business Research, 3(2), $1654 \quad$ 1664.

Stankevičienè, A. \& Liučvaitienè, A. (2012). Intelektinio kapitalo vertinimo aspektai. Verslas: Teorija ir Praktika, 13(1), 79-93.

Sun, Q. \& Xiaolan, M.Z. (2019). Financing intangible capital. Journal of Financial Economics, 132(2), $472-496$.

Svensson, A. (2014). Voluntary disclosure of information on intangibles in corporate. Annual Reports Global Review of Accounting and Finance, 4(1), 133-147.

Teece, J.D. (2000). Managing Intellectual Capital. Oxford University Press, New York.

Vanini, U. \& Rieg, R. (2019). Effects of voluntary intellectual capital disclosure for disclosing firms: A structured literature review. Journal of Applied Accounting Research, 20(3), 349-364

Volkov, D. \& Garanina, T. (2007). Intangible Assets: Importance in the Knowledge-Based Economy and the Role in Value Creation of a Company. SSRN, 539-550.

Wyatt, A. \& Abernethy, A. (2003). Framework for measurement and reporting on intangible assets. Intellectual Property Research Institute of Australia. 1-36. 